\title{
Silvicultural Systems for Restoration of Mahogany in Degraded Landscapes in Africa: Influence of Mixed Rainforest Plantation on Growth and Pest Damage
}

\author{
Emmanuel Opuni-Frimpong1, Nana Yaa Nyarko-Duah², Ebenezer J. D. Belford², \\ Andrew J. Storer ${ }^{3}$ \\ ${ }^{1}$ Forestry Research Institute of Ghana, Kumasi, Ghana \\ ${ }^{2}$ Faculty of Biosciences, Kwame Nkrumah University of Science and Technology, Kumasi, Ghana \\ ${ }^{3}$ School of Forest Resources and Environmental Science, Michigan Technological University, Townsend, USA \\ Email: eofrimpon@csir-forig.org.gh, eopunifr@mtu.edu
}

Received 22 April 2014; revised 3 June 2014; accepted 4 July 2014

Copyright (C) 2014 by authors and Scientific Research Publishing Inc.

This work is licensed under the Creative Commons Attribution International License (CC BY).

http://creativecommons.org/licenses/by/4.0/

(c) (i) Open Access

\section{Abstract}

African mahogany, one of the world's most valuable timber species is threatened by over-exploitation in natural forests and failure of plantations due to attacks by the shoot borer Hypsipyla robusta. Mixed-species plantations has been reported to be an effective component of integrated pest management of major pest in other crops; but there is very limited empirical data on its use for managing Hypsipyla in mahogany mixed stands in West Africa. The aim of this study was to assess the effect of mixed-species stands as management intervention, on the growth of Khaya grandifoliola and Khaya ivorensis in relation to Hypsipyla robusta attack in a 10 ha experimental plantation in the wet evergreen forest type in Ghana. Khaya grandifoliola recorded faster growth than Khaya ivorensis in this forest type though the later naturally grow in this forest type while the former is introduced from the dry forest. Two years after planting, diameter and height growth were greater in the mixed-species stand than the pure stands for $K$. grandifoliola and $K$. ivorensis. Hypsipyla damage was less in the mixed stands of both $K$. grandifoliola and $K$. ivorensis compared to the pure stands, with the $20 \%$ and $10 \%$ Khaya mixed stand recording the lowest attack in both species. It can be recommended that mixed stands of the two Khaya species at $20 \%$ or lower Khaya density might be ideal for reducing the levels of Hypsipyla attack in this type of forest.

\section{Keywords}

African Mahogany, Hypsipyla robusta, Mixed Plantation, Planting Density, Khaya Species

How to cite this paper: Opuni-Frimpong, E., Nyarko-Duah, N. Y., Belford, E. J. D., \& Storer, A. J. (2014). Silvicultural Systems for Restoration of Mahogany in Degraded Landscapes in Africa: Influence of Mixed Rainforest Plantation on Growth and Pest Damage. Open Journal of Forestry, 4, 414-425. http://dx.doi.org/10.4236/ojf.2014.44046 


\section{Introduction}

Establishment of plantations of high value tree species such as the mahoganies is being encouraged to help mitigate the effects of tropical deforestation as well as provide future timber for commercial purposes. Restoring degraded lands with tree plantations are recognised as important additions to the natural forest as a means of increasing forest cover on degraded lands (Seymour \& Hunter, 1999). Forest plantations are seen as the surest way to achieve sustainable forest management in most tropical countries with high deforestation rates and there is increasing rate of plantation establishment throughout the world accounting for five percent (5\%) of global forest cover (FAO, 2001a). The Meliaceae or the "mahogany family", which includes the genera Khaya are among the most valuable timber species in the world (Hawthorne, 1990; Opuni-Frimpong et al., 2008b). This has contributed to an excessive increase in their demand, production and export for plywood and veneer in the last 30 years with little regard to the rate of natural regeneration in most places where it occurs naturally (FAO, 2001b).

The African mahogany plays a major economic role in the international timber trade because of its many desirable quailties, which include its straight grain which is usually free from pockets and voids (Abbiw, 1990). The high demand has led to excessive exploitation threatening the sustainability of its resource base in the natural forest. However, establishment of mahogany plantations in Ghana and elsewhere in the tropics to support the limited resource base in the natural forest has been met with challenges from the shoot borer Hypsipyla robusta, which has resulted in reduced interest in mahogany plantations (Newton et al., 1993; Hauxwell et al., 2001; Opuni-Frimpong et al., 2005, 2008a). Hypsipyla robusta larvae attack seed and fruit capsules and bore into the fresh, succulent shoots of mahogany species, killing the first few centimetres of the shoots (Griffiths, 2001). The growth rate of the tree is thus reduced; heavy and repeated attacks can result in tree death. Hypsipyla robusta larvae destroy the terminal shoot causing the tree to form many side branches which frequently leads to a deformed trunk and stunts growth (Watt, 1994; Mayhew \& Newton, 1998). When attacked by H. robusta the economic value of the tree goes down considerably since relatively straight stem desired for commercial purposes in mahogany in most situations after attacks get compromised.

Biological, chemical and silvicultural control measures, have been examined for managing $H$. robusta with limited success (Hauxwell et al., 2001; Opuni-Frimpong et al., 2008b). One silvicultural method that has received strong advocacy is the use of mixed species plantation that mimics the natural forest. Available literature indicates that mixed species plantation is likely to be effective in managing $H$. robusta for a number of reasons including; host trees are likely to be more difficult for adult pests to locate in mixed species than in monocultures; plant suitability for larvae may be reduced as a result of shading; and natural enemies may be more abundant or effective in mixed stands as other species could provide a refuge for natural enemies (Watt, 1994; Mayhew \& Newton, 1998; Hauxwell et al., 2001; Opuni-Frimpong et al., 2005, 2008a, 2013).

To aid in sustainable forest management and reduce dependency on the natural forest, effective measures to establish mahogany plantations while avoiding the shoot borer menace must be identified. This study was therefore undertaken to: 1) assess the effect of different densities of mixed-species plantation on the growth of the African mahogany, and 2) assess the effect of different densities of mixed-species plantation on Hypsipyla robusta attacks on mahoganies. The study was conducted in a ten hectare plot at the Tano-Nimiri Forest Reserve in the wet evergreen forest type in Ghana.

\section{Materials Methods}

\subsection{Site Description}

The study area is an experimental plot established by a team of research scientists from the Forestry Research Institute of Ghana in Tano-Nimiri, a degraded forest reserve, which is undergoing reforestation through col- laboration between Samartex Timber and Plywood Company limited and surrounding communities. The area is a concession for Samartex located in Samreboi, a town in the western region of Ghana which is within the wet evergreen forest type in Ghana. It lies between altitudes of between $60 \mathrm{~m}$ and $180 \mathrm{~m}$ with peaks rising to as high as $260 \mathrm{~m}$ (Figure 1). The annual rainfall is between $1750 \mathrm{~mm}$ and $2000 \mathrm{~mm}$ (Hall \& Swaine, 1981; Asankragwa, 2006). The average low temperature of the area is $21^{\circ} \mathrm{C}$ and average high temperature of the area is $32^{\circ} \mathrm{C}$. Relative humidity is also between $70 \%$ and $85 \%$ perseason (Forest Management Unit 10, 2001).

\subsection{Experimental Design}

The experimental site is a ten (10) hectare area, laid out in a randomized complete block design, with four 
blocks. Each block was divided into 10 plots with varying percentages of Khaya grandifoliola C.DC (Kg), Khaya ivorensis A. Chew (Ki), Heritieria utilis Sprague (Hu), Terminalia superba Engl and Diels (Ts) and Entandrophragma angolense Welw. (Ea). All the species grow naturally in the area except $K$. grandifoliola. Each plot had a dimension of about nineteen meters by ninety meters $(19 \mathrm{~m} \times 90 \mathrm{~m})$ with a spacing of three meters (3 $\mathrm{m})$ between trees. In each plot, a total of 220 individual trees were planted. The present data were collected when the trees were two years old.

\subsection{Data Collection}

The key species for this study were Khaya grandifoliola and Khaya ivorensis, which were planted at relative densities of $100 \% \mathrm{~s}$ (pure stand), $60 \%, 50 \%, 40 \%, 20 \%$ and $10 \%$ per plot with an even mixture of the 3 companion species (Heritieria utilis Sprague, Terminalia superba and Entandrophragma angolense). A systematic random sampling method was used to collect the data. In each block, an average of thirty (30) trees per plot were selected and assessed for each Khaya species. On the other hand 15 trees were assessed for each of the companion trees. The growth measurements taken were total tree height (Ht), diameter at breast height (DBH; measured at a standard height of $1.3 \mathrm{~m}$ ) and height at first fork (HtF) for the Khaya species but only diameter and height were measured for the companion species.

Damage by $H$. robusta was assessed by recording total shoots attacked (TSA), total number of shoots with fresh attack (TFA), total number of dead shoots (TDS), number of total shoots (TS) sprouted in response to Hypsipyla attack, and the length of the longest dead shoot (LDS). In all about 746 trees were sampled for Khaya grandifoliola and 467 for Khaya ivorensis.

\subsection{Data Analysis}

An analysis of variance (ANOVA) using the General Linear Model (GLM) of the SPSS statistical package (version 16) was used to test for differences between the means of the parameters assessed at the five percent significance level $(P<0.05)$. The model chosen allows for pair-wise and multiple comparisons of the treatments. Tree volume measurements were calculated using Newbould, 1967: $\mathrm{V}=1 / 2\left(\mathrm{~B}_{\mathrm{dbh}} \times \mathrm{Ht}\right)$, where $\mathrm{V}$ is volume, $\mathrm{B}_{\mathrm{dbh}}$ is the basal area of diameter at breast height and $\mathrm{Ht}$ is tree height.

\section{Results}

\subsection{Growth of Khaya Species}

Khaya grandifoliola demonstrated a better growth performance than Khaya ivorensis in all planting densities with $10 \%$ showing the best growth performance for $K$. grandifoliola $(6.44 \mathrm{~cm}$ diameter, $4.90 \mathrm{~m}$ height and $0.0105 \mathrm{~m}^{3}$ volume) and $60 \%$ for $K$. ivorensis $\left(5.27 \mathrm{~cm}\right.$ diameter, $4.38 \mathrm{~m}$ height and $0.0057 \mathrm{~m}^{3}$ volume) (Table 1). No differences were observed in growth with relative Khaya density for both diameter and height of $K$. grandifoliola ( $P=0.172$ and 0.463 respectively, Table 2$)$, but for $K$. ivorensis, growth differences with relative Khaya density were observed for both diameter and height $(P=0.000$, Table 3$)$.

Generally, Terminalia superba had a greater growth rate than the other mixed species, with an average diameter of $7.2 \mathrm{~cm}$ and average height of $4.7 \mathrm{~m}$. Entandrophragma angolense had an average diameter of $3.1 \mathrm{~cm}$ and average height of $3.1 \mathrm{~m}$, while, Heritieria utilis had an average diameter of $2.0 \mathrm{~cm}$ and average height of 2.3 $\mathrm{m}$. Khaya grandifoliola had an average diameter of $6.2 \mathrm{~cm}$ and height of $4.8 \mathrm{~m}$ and Khaya ivorensis had an average diameter of $4.5 \mathrm{~cm}$ and height of $3.9 \mathrm{~m}$ (Figure 2 and Figure 3).

In general $K$. ivorensis showed less forking than $K$. grandifoliola, except at $60 \%$ density (Figure 4) in the mixed plantings two years after planting in the field. There were significant differences among densities for both $K$. grandifoliola and $K$. ivorensis in mean height at first fork $(P=0.010$ and $P=0.018$, respectively, Table 2 and Table 3). The density which had the best height to first fork was $100 \%$ planting density at $2.16 \mathrm{~m}$ for $\mathrm{K}$. grandifoliola and $60 \%$ planting density at $1.58 \mathrm{~m}$ for K. ivorensis (Figure 4).

\subsection{Hypsipyla robusta Attacks on Khaya Species}

The number of shoots with fresh attack recorded was very low for both species, with $K$. grandifoliola recording a range of 0.017 ( $40 \%$ density) to 0.098 (at 100\% density) and a range of 0.00 (at $60 \%$ density) to 0.053 (at 100\% 


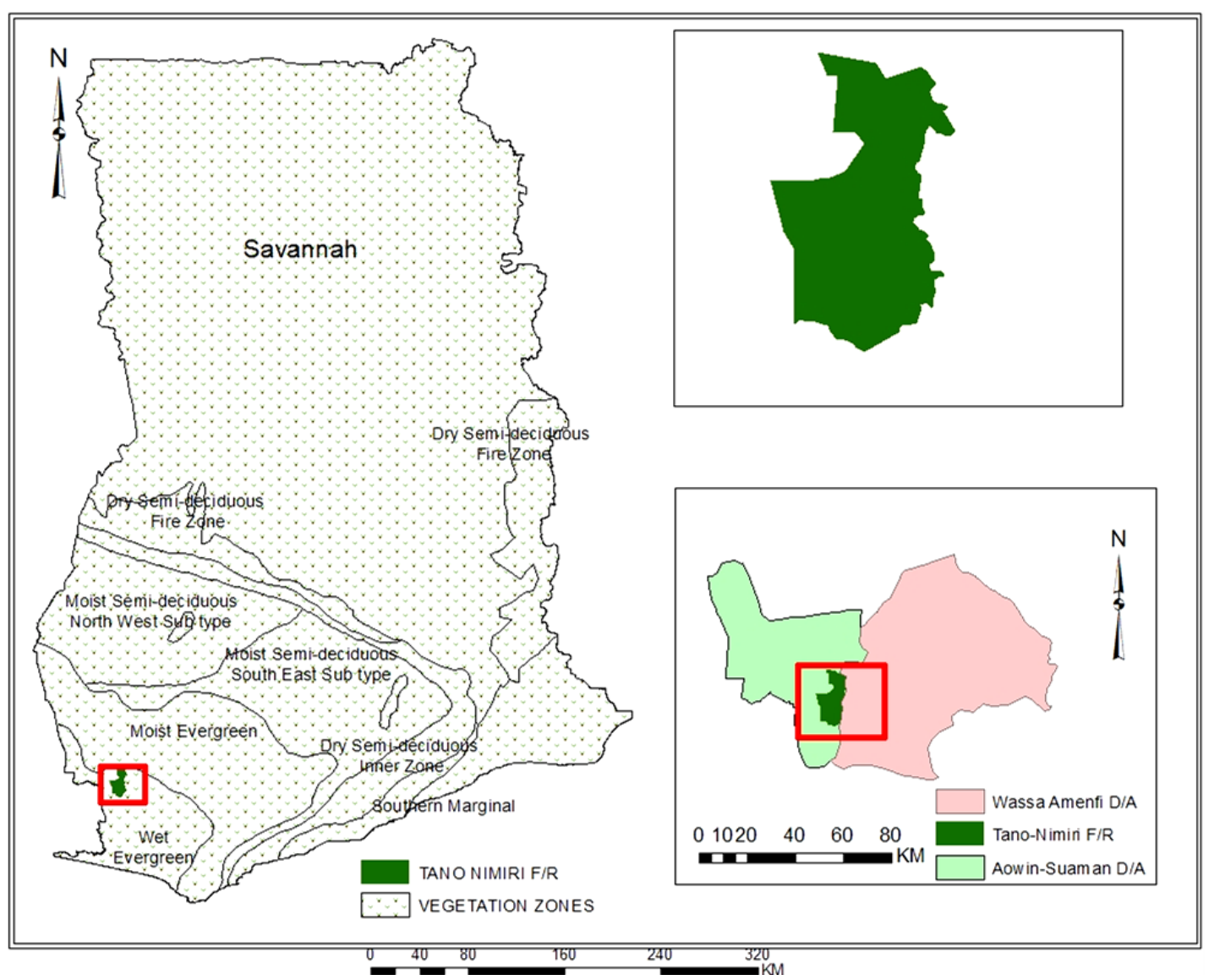

Figure 1. Vegetation map of Ghana showing the location of Tano-Numeri forest reserve.

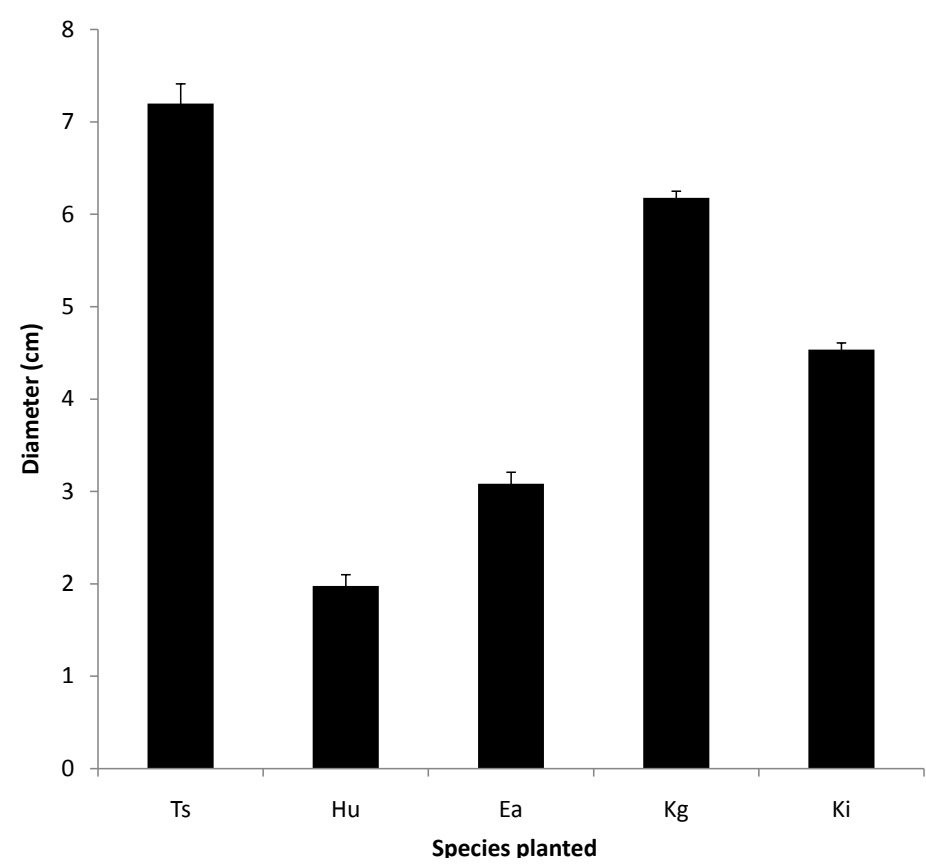

Figure 2. Mean diameter of Terminalia superba (Ts), Heritieria utilis (Hu), Entandrophragma angolense (Ea), Khaya grandifoliola (Kg) and Khaya ivorensis (Ki) inmixed planting. 


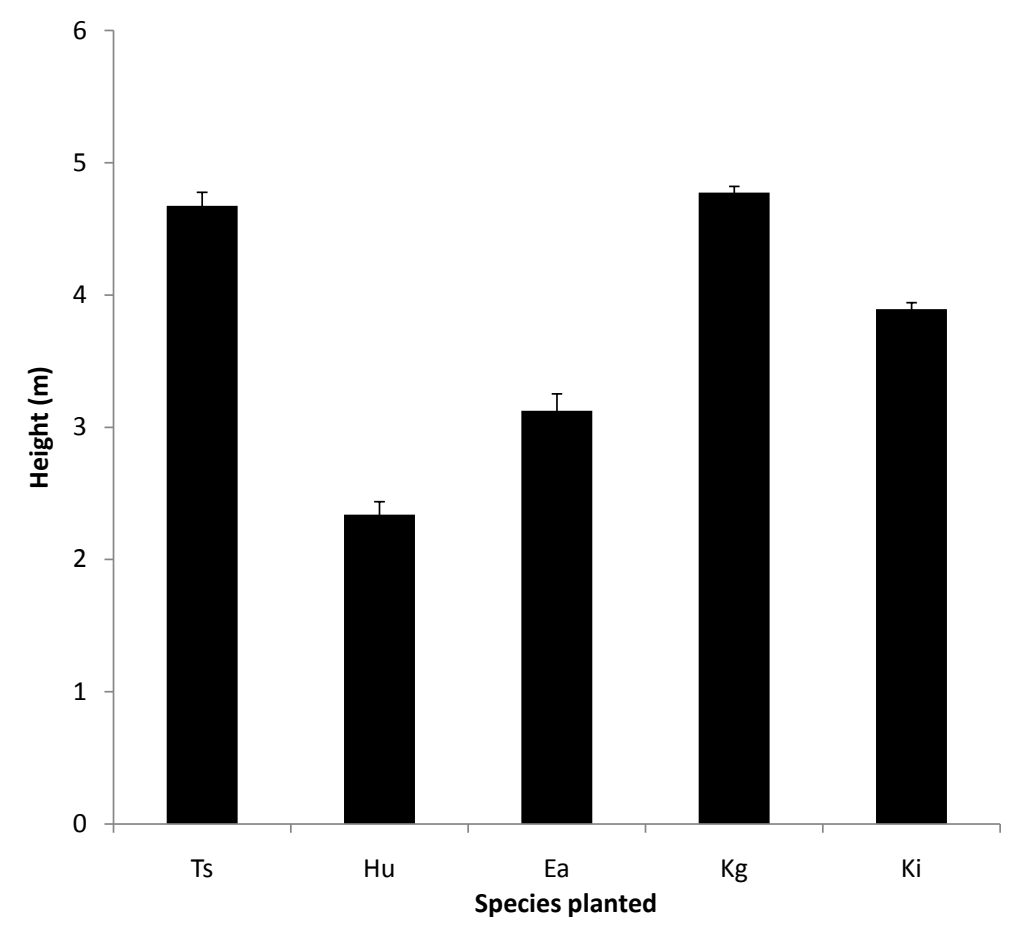

Figure 3. Mean height of Terminalia superba (Ts), Heritieria utilis (Hu), Entandrophragma angolense (Ea), Khaya grandifoliola (Kg) and Khaya ivorensis $(\mathrm{Ki})$ in mixed planting.

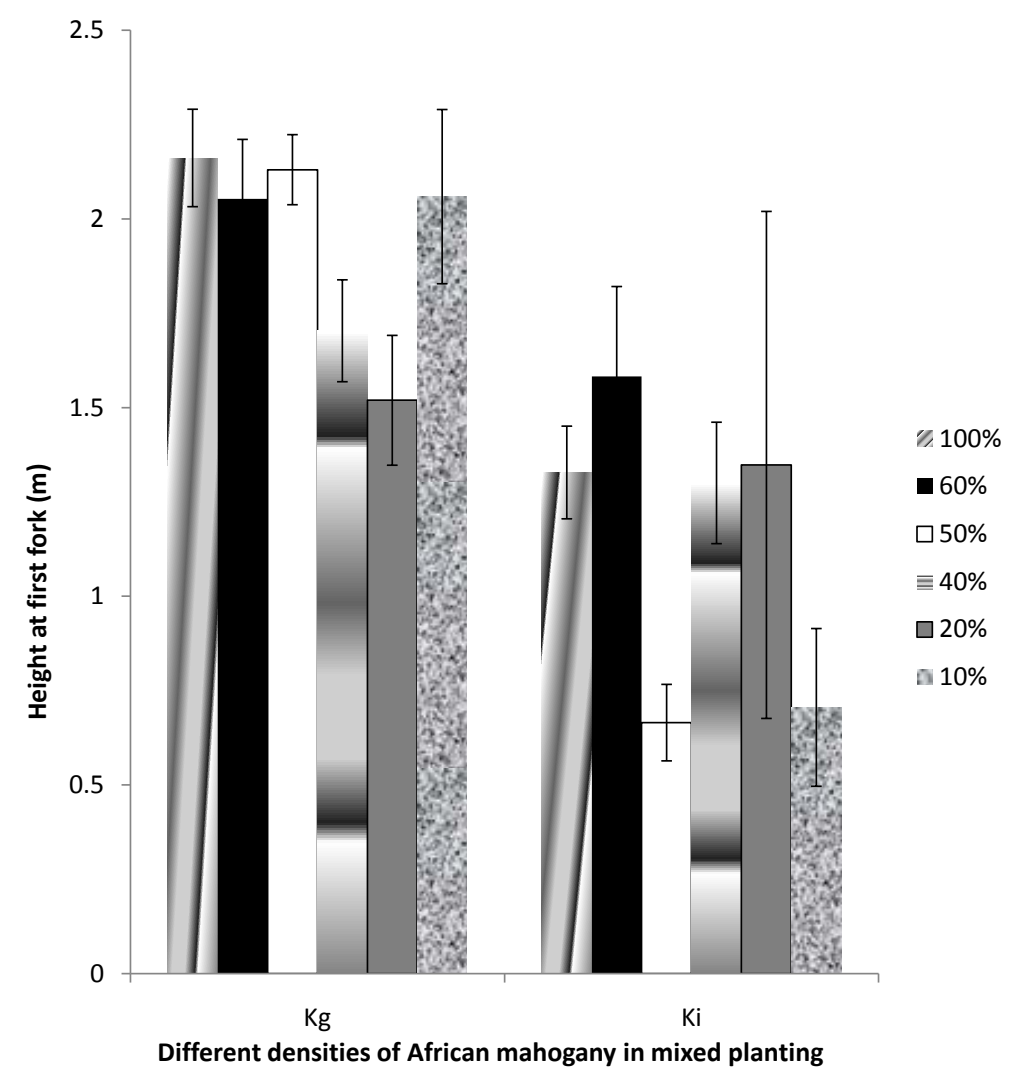

Figure 4. Mean height at first fork of Khaya grandifoliola (Kg) and Khaya ivorensis (Ki) in six different planting densities. 
Table 1. Mean tree size of Khaya grandifoliola (Kg) and Khaya ivorensis (Ki) at age 2 in a wet evergreen forest.

\begin{tabular}{ccccccc}
\hline & \multicolumn{3}{c}{ Kg } & & \multicolumn{2}{c}{ Ki } \\
\hline Density & Height $(\mathrm{m})$ & Diameter $(\mathrm{cm})$ & Volume $\left(\mathrm{m}^{3}\right)$ & Height $(\mathrm{m})$ & Diameter $(\mathrm{cm})$ & ${\text { Volume }\left(\mathrm{m}^{3}\right)}$ \\
$100 \%$ & $4.93(0.11)$ & $6.39(0.18)$ & $0.0096(0.0006)$ & $3.77(0.09)$ & $4.46(0.13)$ & $0.0036(0.0003)$ \\
$60 \%$ & $4.81(0.13)$ & $6.19(0.19)$ & $0.0092(0.0007)$ & $4.38(0.19)$ & $5.27(0.23)$ & $0.0057(0.0006)$ \\
$50 \%$ & $4.73(0.09)$ & $6.13(0.12)$ & $0.0084(0.0004)$ & $3.67(0.08)$ & $4.20(0.13)$ & $0.0032(0.0003)$ \\
$40 \%$ & $4.60(0.11)$ & $5.75(0.19)$ & $0.0075(0.0006)$ & $4.28(0.12)$ & $4.96(0.17)$ & $0.0049(0.0004)$ \\
$20 \%$ & $4.76(0.15)$ & $6.24(0.21)$ & $0.0087(0.0008)$ & $3.76(0.13)$ & $4.41(0.24)$ & $0.0041(0.0004)$ \\
$10 \%$ & $4.90(0.20)$ & $6.44(0.31)$ & $0.0105(0.0013)$ & $3.79(0.17)$ & $4.20(0.27)$ & $0.0035(0.0005)$ \\
\hline
\end{tabular}

Note: Standard errors for means given in brackets.

Table 2. Analysis of variance results for growth and damage parameters for Khaya grandifoliola (Ki).

\begin{tabular}{|c|c|c|c|c|c|}
\hline & Sum of Squares & Df & Mean Square & $\mathrm{F}$ & $P$-value \\
\hline Diameter & 30.734 & 5 & 6.147 & 1.550 & 0.172 \\
\hline Height & 8.242 & 5 & 1.648 & 0.927 & 0.463 \\
\hline Height at first fork & 35.390 & 5 & 7.078 & 3.044 & 0.010 \\
\hline Total shoots & 80.007 & 5 & 16.001 & 3.161 & 0.008 \\
\hline No. of shoots attacked & 16.576 & 5 & 3.315 & 1.788 & 0.113 \\
\hline No. of fresh attack & 0.500 & 5 & 0.100 & 1.930 & 0.087 \\
\hline No. of dead shoots & 27.814 & 5 & 5.563 & 7.142 & 0.000 \\
\hline Length of longest dead shoot & 5660.187 & 5 & 1132.037 & 3.712 & 0.003 \\
\hline
\end{tabular}

Table 3. Analysis of variance results for growth and damage parameters for Khaya ivorensis (Ki).

\begin{tabular}{|c|c|c|c|c|c|}
\hline & Sum of Squares & Df & Mean Square & $\mathrm{F}$ & $P$-value \\
\hline Diameter & 58.444 & 5 & 11.689 & 5.023 & 0.000 \\
\hline Height & 32.502 & 5 & 6.500 & 6.014 & 0.000 \\
\hline Height at first fork & 52.211 & 5 & 10.442 & 2.775 & 0.018 \\
\hline Total shoots & 30.419 & 5 & 6.084 & 4.293 & 0.001 \\
\hline No. of shoots attacked & 23.967 & 5 & 4.793 & 6.682 & 0.000 \\
\hline No. of fresh attack & 0.200 & 5 & 0.040 & 1.378 & 0.231 \\
\hline No. of dead shoots & 6.061 & 5 & 1.212 & 3.860 & 0.002 \\
\hline Length of longest dead shoot & 2184.452 & 5 & 436.890 & 3.080 & 0.010 \\
\hline
\end{tabular}

density) for K. ivorensis (Table 4). Statistically, there were no significant differences among densities in fresh shoot attacks for either Khaya species (Table 2 and Table 3).

The results two years after planting in the field revealed that $K$. grandifoliola responded to Hypsipyla robusta attack with more branches than K. ivorensis (Figure 5). The number of shoots of K. grandifoliola and K. ivorensis attacked by Hypsipyla robusta was higher in K. grandifoliola than in K. ivorensis. The highest number of shoots attacked for $K$. grandifoliola was 1.39 obtained at 50\% density for the mixed-species stands and lowest number of shoots attacked was 0.89 (at 10\% density) (Figure 6). The highest number of shoots attacked for $K$. ivorensis was 0.89 (at $100 \%$ density) and lowest was 0.32 (at 20\% density). For K. ivorensis, the number of total shoots ranged from 1.43 (at 20\% planting density) to 2.16 (at 60\% planting density) while for K. grandifoliola the number of total shoots ranged from 2.47 (at 10\% density) to 3.38 (at $100 \%$ planting density).

K. grandifoliola recorded the lowest number of dead shoots at 0.15 (at $40 \%$ planting density) and the highest at 0.74 (at $60 \%$ planting density) and the length of the longest dead shoot at $10 \%$ planting density (Table 5). The number of dead shoots for $K$. ivorensis ranged from 0.085 (at 20\% planting density) to 0.37 (at $100 \%$ planting density) (Table 5). 


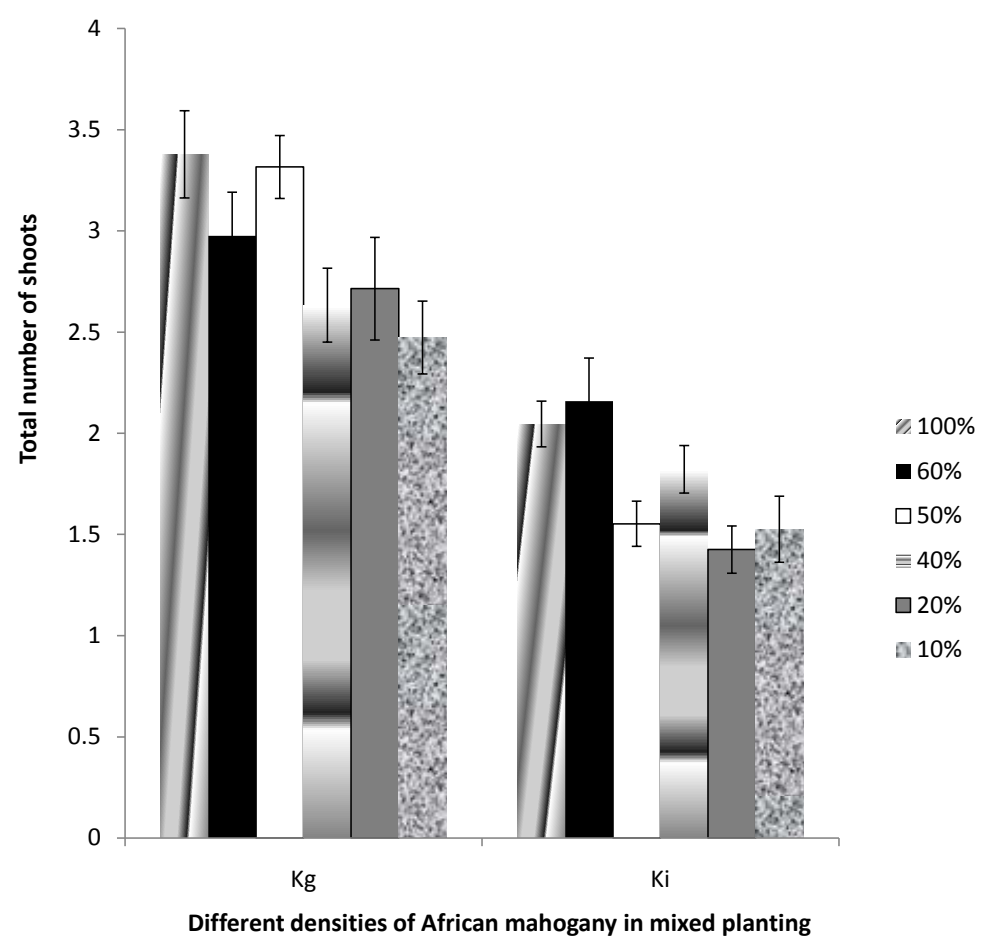

Figure 5. Mean total number of shoots of Khaya grandifoliola (Kg) and Khaya ivorensis (Ki) in six different planting densities.

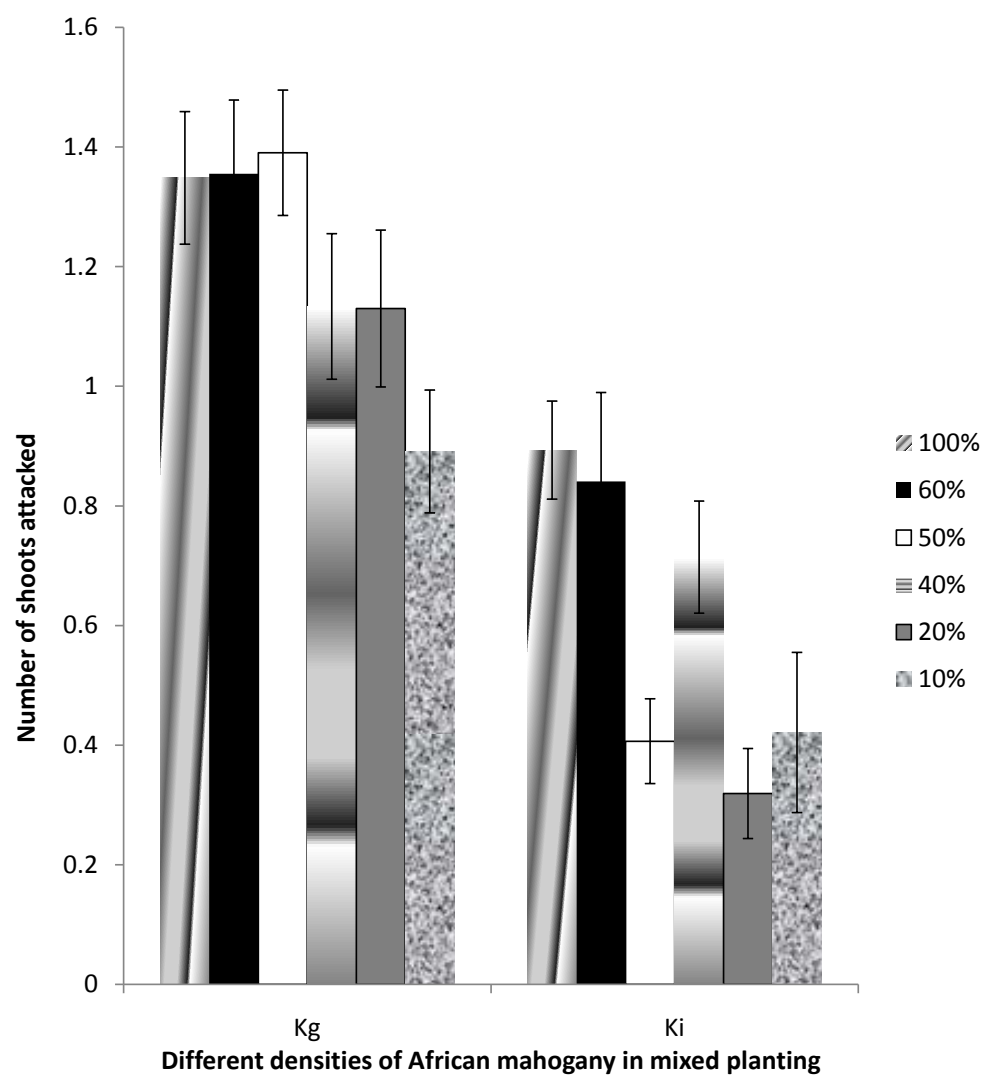

Figure 6. Mean total number of shoots attacked of Khaya grandifoliola (Kg) and Khaya ivorensis (Ki) in six different planting densities. 
Table 4. Mean number of fresh attack \pm SE for different planting densities of Khaya grandifoliola $(\mathrm{Kg})$ and Khaya ivorensis (Ki).

\begin{tabular}{ccc}
\hline Density & $\mathrm{Kg}$ & $\mathrm{Ki}$ \\
\hline $100 \%$ & $0.098(0.028)$ & $0.053(0.019)$ \\
$60 \%$ & $0.049(0.019)$ & $0.000(0.000)$ \\
$50 \%$ & $0.048(0.015)$ & $0.008(0.008)$ \\
$40 \%$ & $0.017(0.012)$ & $0.048(0.023)$ \\
$20 \%$ & $0.026(0.018)$ & $0.021(0.021)$ \\
$10 \%$ & $0.036(0.025)$ & $0.027(0.027)$ \\
\hline
\end{tabular}

Note: Standard errors for means given in brackets.

Table 5. Mean number of dead shoots and length of longest dead shoots \pm SE for different planting densities of Khaya grandifoliola $(\mathrm{Kg})$ and Khaya ivorensis (Ki).

\begin{tabular}{ccc}
\hline & Dead shoots & \\
\hline Density & $\mathrm{Kg}$ & $\mathrm{Ki}$ \\
\hline $100 \%$ & $0.447(0.073)$ & $0.374(0.062)$ \\
$60 \%$ & $0.744(0.101)$ & $0.295(0.101)$ \\
$50 \%$ & $0.539(0.064)$ & $0.098(0.033)$ \\
$40 \%$ & $0.15(0.044)$ & $0.214(0.054)$ \\
$20 \%$ & $0.675(0.105)$ & $0.081(0.041)$ \\
$10 \%$ & $0.273(0.074)$ & $0.211(0.120)$ \\
\hline
\end{tabular}

Note: Standard errors for means given in brackets.

\section{Discussion}

\subsection{Growth of Khaya Species}

Two years after planting Khaya grandifoliola and Khaya ivorensis in a mixed planting of different densities with Terminalia superba, Entandrophragma angolense and Heritieria utilis which are all important commercial timber trees in the tropics, differences were displayed for growth in diameter between the planting densities with the $10 \%$ density having the best increase in girth for K. grandifoliola and $60 \%$ for $K$. ivorensis. K. grandifoliola, however, did not demonstrate differences between mixed-planting densities for growth in height. This trend is similar to what is reported for monocultures and mixed plantations of Eucalyptus and Acacia (Khanna, 1997; Parrotta, 1999), Monocultures and mixed plantations of poplar species and Alus glotinosa (Hansen \& Dawson, 1982). Also study conducted in the dry semideciduous forest in Ghana for mixed plantation of $K$ grandifoliola with Terminlia superba and Cedrela odorata followed a similar trend (Opuni-Frimpong et al., 2013). The relative slow growth rate of the companion species might have given advantage to the faster growing $K$. grandifoliola, exposing it to more light and could photosynthesize more effectively than the other species, leading to quicker growth rate (Hawthorne, 1995; Poorter et al., 2004; Petit \& Montagnini, 2006). On the other hand, there were significant differences between planting densities for growth in height and diameter of $K$. ivorensis trees, with the $60 \% \mathrm{~K}$. ivorensis mixed stands having the best growth. This reveals that different species may require different treatments in mixed density planting. Even though the two species are of the same genus, they performed better under different mixed densities and thus each species requires some compatible level of mixtures to enhance the efficient use of resources in mixed-stands for productivity as observed by Forrester et al. (2006) and Kelty (2006). Height at first fork was recorded for both Khaya species to determine the harvestable bole length for the trees and again in this case each species performed better differently in density mixed planting.

The study conducted in the wet evergreen forest zone of Ghana, which is the natural range of $K$. ivorensis (Hall \& Swaine, 1981; Oteng-Amoako, 2006), observed that K. grandifoliola, which naturally occurs in dry semideciduous forests (Poorter et al., 2004), showed a better growth performance than K. ivorensis in all of the 
six mixed-densities planted. This could have been as a result of $K$. grandifoliola's ability to adapt to more favourable environmental conditions in an ecological zone which has a better rainfall regime leading to its faster growth. Opuni-Frimpong et al. (2008a) also suggested that improved growth characteristics exhibited by Khaya anthotheca (genetically similar to K. grandifoliola) in a relatively moist forest as compared to its natural range of drier forests could have been as a result of better environmental conditions provided. This proves that species may have different use-efficiency for relevant resource like good rainfall pattern which could affect plants growth and species distribution (Grijpma, 1976; Swaine, 1996; Engelbrecht et al., 2007).

\subsection{Hypsipyla robusta Attacks on Khaya Species}

Silvicultural interventions to manage mahogany shoots borer (Hypsipyla robusta) problems and maximize growth of trees for timber in mahogany plantations, try to interfere with the mahogany shoot borer's ability to locate the host plant, reduce host suitability, encourage natural enemies and assist recovery of the trees after attack (Hauxwell et al., 2001). These measures include planting vigorous seedlings at good sites together with other plant species that may physically obstruct or may release chemicals that interfere with the chemical cues that help the shoot borer to locate the host plant (Opuni-Frimpong et al., 2005; Hauxwell et al., 2001; Griffiths, 2001).

Branching is one of the main features that expresses the effects of $H$. robusta attack. This occurrence has also been observed by Griffiths (2001); Nair (2001); Opuni-Frimpong et al. (2008b), whose work ascertained that frequent attacks on young plants generally lead to poor quality timber. The results of this study also showed that branching occurred in the mahogany trees in all six planting densities (pure and mixed-species stands) resulting in multiple shoots. The number of new shoots produced showed the mahogany's ability to recover from shoot borer attack. K. grandifoliola had more shoots than K. ivorensis which implied that K. grandifoliola had more $H$. robusta attack. For pure stands (100\% planting density of each species) $K$. grandifoliola had $41 \%$ more shoots than $K$. ivorensis. This could possibly be because $K$. grandifoliola is more vulnerable to the mahogany shoot borer's attack than K. ivorensis. Similar findings were made by Opuni-Frimpong et al. (2008a), whose study on African mahogany species showed that $K$. anthotheca was more susceptible to $H$. robusta attack than $K$. ivorensis. Taller mahogany trees has been observed to attract higher Hypsipyla attacks in plantations (Cipiao et al., 2009; Perez-Salicrup \& Esquivel, 2008; Opuni-Frimpong et al., 2008, 2013) and thus K. grandifoliola with its fast growth in the mixed plantation was more susceptible to Hypsipyla attack.

The lowest levels of $H$. robusta attack were observed in the $20 \%$ and lower planting densities for both Khaya species. This observation corroborates earlier reports that lower densities of mahogany in mixture stands tend to make it difficult for the mahogany shoot borer to locate the Khaya species, consequently reducing the host concentration of the pest (Opuni-Frimpong, et al., 2005; Hauxwell et al., 2001; Griffiths, 2001; Kelty, et al., 2006).

Even though the effect of shade was not explicitly examined in this study, it was observed that low levels of attack by $H$. robusta were recorded in areas where $K$. grandifoliola and $K$. ivorensis were predominantly shaded by other plants in the mixture stands; this observation corresponds to a study conducted by Opuni-Frimpong et al. (2008b), which examined the effect of canopy shade on some mahogany species. The results of that study indicated that, canopy shade decreased $H$. robusta attack levels in the mahogany species studied; however, it also led to a reduction in growth of the species concerned as observed in this study for $K$. ivorensis. The number of dead shoots (die-back) for both Khaya species gives us an indication of the levels and extent of $H$. robusta attacks on the mahogany trees. It is also an indication of the mahogany's ability to recover from the incidence of shoot borer attack and produce new shoots. According to Hauxwell et al. (2001), Newton et al. (1999), and Opuni-Frimpong (2006), this observation may be as a result of the Khaya species mechanism of self-pruning which is attributed to the species.

Of the six densities studied, mixture stands with equal percentages of all species (20\% density) and the $10 \%$ density had the lowest level of $H$. robusta attacks. Mixed species plantation according to Opuni-Frimpong et al. (2013), Kelty (2006), Haux-well et al. (2001), Watt (1994), and Mayhew and Newton (1998), may help in reducing the incidence of $H$. robusta infestation in mahogany plantations. This expression of low levels of $H$. robusta infestation at lower densities of Khaya species may be attributed to stronger interference in chemical cues from companion species disrupting Hypsipyla ability to easily identifying host trees (Matsumoto \& Kotulai, 2000). Again the companion species may have made available more diverse habitats to support greater population of natural enemies of Hypsipyla and potentially by providing a refuge for natural enemies leading to low at- 
tacks (Watt, 1992; Parker et al., 2013).

\section{Conclusion}

The study demonstrated that mixture stands at different densities had effect on the growth and incidence of $H$. robusta infestation on the Khaya species. The two species were observed to behave differently under different density of mixed stands demonstrating that each species requires different treatment of mixture for better productivity in the field. The mixed density which had the most mitigating effect on the levels of $H$. robusta attacks for both Khaya species were $20 \%$ and lower density of the Khaya species in the mixture stand. Although the study was conducted in the wet evergreen forest zone of Ghana, which is not within the natural range of $K$. grandifoliola, it nonetheless showed better growth performance than $K$. ivorensis which naturally occurs within the forest type where the study was conducted. The relatively better performance of $K$. grandifoliola in the wet evergreen forest type makes it a favourable candidate for plantation establishment in this type of forest. The common assumption that mixed plantation reduces the attack in mahogany plantation to some extent was confirmed in this study. However, each species of mahogany may require detailed study to identify the most suitable density of mixture that will enhance growth as well as reduce the negative impacts of Hypsipyla attack in plantations.

\section{Acknowledgements}

This study was funded by the International Tropical Timber Organization (ITTO Reference 023/10A and PD528Rev1F)) and the CSIR-Forestry Research Institute of Ghana. Our sincere gratitude goes to the Samartex Timber and Plywood Company Limited for providing the study site and other logistics during the establishment and assessment periods of the project. We acknowledge Richard Nsenkyire (General Manager), KKF Ghartey (Forestry Consultant) and Crispin Suglo for their support at Samartex. We also thank Sandra Acheampong Owusu, Godwin Andoh Kwarkye, Collins Baah Darko and other field technicians and students at the CSIR-Forestry Research Institute of Ghana and Faculty of Forest Resources Technology, KNUST, for their help in field data collection.

\section{References}

Abbiw, D. (1990). Useful Plants of Ghana: West African Uses of Wild and Cultivated Plants (337 p). London: Intermediate Technology Publications, Royal Botanic Gardens, Kew.

Asankragwa DADU Office (2006). Annual Report. Wassa Amenfi West District: Asankragwa DADU Office.

Cipiao, L., Bandeira, R. R., \& Sitoe, S. M. (2009). Incidence of Hypsipyla Sp. (Lepidoptera: Pyralidae) and Its Population Distribution on Khaya anthothe, 18-23ca (Meliacae) Stands in the Manica Province, Central Mozambique (8 p). Buenos Aires: XIII World Forestry Congress.

Engelbrecht, B. M. J., Comita, L. S., Condit, R., Kursar, T. A., Tyree, M. T., Turner, B. L., \& Hubbell, S. P. (2007). Drought Sensitivity Shapes Species Distribution Patterns in Tropical Forest. Nature, 447, 80-82. http://dx.doi.org/10.1038/nature05747

FAO (2001a). Global Forest Resources Assessment 2000. Main Report. FAO Forestry Paper 140 (479 p). Rome: Food and Agriculture Organisation of the United Nations.

FAO (2001b). Promotion of Valuable Hardwood Plantations in the Tropics. A Global Overview. In D. J. Mead (Ed.), Forest Plantations Thematic Papers. Forest Resources Development Service Working Paper FP/4. Rome: FAO.

FC Ghana (2001). Forest Management Unit 10. Ghana: Forest Services Division, Mameri Group of Forest Reserves, Prepared by the Regional Planning Team, Forestry Commission.

Forrester, D. I., Bauhus, J., Cowie, A. L., \& Vanclay, J. K. (2006). Mixed-Species Plantations of Eucalyptus with NitrogenFixing Trees: A Review. Forest Ecology and Management; Special Issue: Improving Productivity in Mixed-Species Plantations, 233, 211-230

Griffiths, M. W. (2001). The Biology and Ecology of Hypsipyla Shoot Borers. In R. B. Floyd, \& C. Hauxwell (Eds.), Hypsipyla Shoot Borers in Meliaceae: Proceedings of an International Workshop (pp. 74-80). Canberra: Australian Centre for International Agricultural Research (ACIAR).

Grijpma, P. (1976). Resistance of Meliaceae against the Shoot Borer Hypsipyla with Particular Reference to Toona ciliate M.J. Roem.Var. Australia (F.v. Muell) C.D.C. In J. Burley, \& B. T. Styles (Eds.), Tropical Trees: Variation, Breeding and Conservation (pp. 69-78). London: Academic Press. 
Hall, J. S., \& Swain, M. D. (1981). Distribution and Ecology of Vascular Plants in a Tropical Rain Forest Vegetation in Ghana (83 p). The Hague: Dr. W. Junk Publisher. http://dx.doi.org/10.1007/978-94-009-8650-3

Hansen, E. A., \& Dawson, J. O. (1982). Effect of Alnus glutinosa on Hybrid Poplar Height Growth in a Shortrotation Intensively Cultured Plantations. Forest Science, 28, 49-59.

Hauxwell, C., Mayhew, J., \& Newton, A. (2001). Silvicultural Management of Hypsipyla. In R. B. Floyd, \& C. Hauxwell (Eds.), Hypsipyla Shoot Borers in Meliaceae (pp. 151-163). Canberra: ACIAR.

Hawthorne, W. D., \& Abu-Juan, M. (1995). Forest Protection in Ghana. Switzerland and Cambridge: IUCN Gland.

Hawthorne, W. D. (1990). Field Guide to the Forest Trees of Ghana (278 p). Chatham: Natural Resources Institute, for Overseas Development Administration, London.

Kelty, M. J. (2006). The Role of Species Mixtures in Plantation Forestry. Forest Ecology and Management; Special Issue: Improving Productivity in Mixed-Species Plantations, 233, 195-204. http://dx.doi.org/10.1016/j.foreco.2006.05.011

Khanna, P. K. (1997). Comparison of Growth and Nutrition of Young Monocultures and Mixed Stands of Eucalyptus globules and Acacia mearnsii. Forest Ecology and Management, 94, 105-113. http://dx.doi.org/10.1016/S0378-1127(96)03971-0

Matsumoto, K., \& Kotulai, J. B. (2000). Insect Pest of Mahogany with Particular Reference to Shoot Borers. In H. H. Chang, \& K. Matsumoto (Eds.), Proceedings of the Seminar on High Value Timber Species for Plantation Establishment-Teak and Mahoganies (pp. 67-79). Tsukuba: JIRCAS.

Mayhew, J. E., \& Newton, A. C. (1998). The Silviculture of Mahogany (226 p). Wallingford: CABI Publishing.

Nair, K. S. S. (2001). Pest Outbreaks in Tropical Forest Plantations. Is There a Greater Risk for Exotic Tree Species? Bogor: Center for International Forestry Research (CIFOR).

Newbould, P. J. (1967). Methods for Estimating the Primary Production of Forest (p. 62). Oxford: Blackwell Scientific.

Newton, A. C., Watt, A. D., Lopez, F., Cornelius, J. P., Mesén, J. F., \& Corea, E. A. (1999). Genetic Variation in Host Susceptibility to Attack by the Mahogany Shoot Borer, Hypsipyla grandella (Zeller). Agricultural and Forest Entomology, 1, 11-18. http://dx.doi.org/10.1046/j.1461-9563.1999.00002.x

Newton, A. C., Baker, P., Ramnarine, S., Mesen, J. F., \& Leakey, R. R. B. (1993). The Mahogany Shoot Borer-Prospects for Control. Forest Ecology and Management, 57, 301-328. http://dx.doi.org/10.1016/0378-1127(93)90179-Q

Opuni-Frimpong, E., Opoku, S. M., Storer, A. J., Burton, A. J., \& Yeboah, D. (2013). Productivity, Pest Tolerance and Carbon Sequestration of Khaya grandifoliola in the Dry Semi-Deciduous Forest of Ghana: A Comparison in Pure Stands and Mixed Stands. New Forest, 44, 863-879. http://dx.doi.org/10.1007/s11056-013-9376-6

Opuni-Frimpong, E. (2006). Improving Productivity and Conservation of African Mahogany: Genetic Selection, Propagation and Silvicultural Management of Hypsipyla robusta (Moore) (178 p.). Ph.D. Thesis, Houghton: The Graduate School of Michigan Technology University.

Opuni-Frimpong, E., Karnosky, D. F., Storer, A. J., \& Cobbinah, J. R. (2005). The Effect of Mixed Species Stands on Hypsipyla Attack on Mahogany Trees in the Moist Semi-Deciduous Forest of Ghana. The International Forestry Review, 7, 57.

Opuni-Frimpong, E., Karnosky, D. F., Storer, A. J., \& Cobbinah, J. R., (2008b). Silvicultural Systems for Plantation Mahogany in Africa: Influences of Canopy Shade on Tree Growth and Pest Damage. Forest Ecology and Management. Special Issue; Sustainable Management of High Value Timber Species of the Meliaceae, 255.

Opuni-Frimpong, E., Karnosky, D. F., Storer, A.J., Abeney, E. A., \& Cobbinah, J. R. (2008a). Relative Susceptibility of Four Species of African Mahogany to the Shoot Borer Hypsipyla robusta (Lepidoptera: Pyralidae) in the Moist Semideciduous Forest of Ghana. Forest Ecology and Management. Special Issue; Sustainable Management of High Value Timber Species of the Meliaceae, 255, 313-319.

Oteng-Amoako, A. A. (2006). 100 Tropical African Timber Trees from Ghana: Tree Description and Wood Identification with Notes on Silviculture, Ethonobotany and Uses (304 p). Accra: Graphic Packaging.

Parrotta, J. A. (1999). Productivity, Nutrient Cycling, and Succession in Single- and Mixed-Species Plantations of Casuarina equisetifolia, Eucalyptus robusta, and Leucaena leucocephala in Puerto Rico. Forest Ecology and Management, 124, 4577. http://dx.doi.org/10.1016/S0378-1127(99)00049-3

Perez-Salicrup, D. R., \& Esquivel, R. (2008). Tree Infection by Hypsipyla grandella in Swietenia macrophylla and Cedrela odorata (Meliaceae) in Mexico's Southern Yucatan Peninsula. Special Issue: Sustainable Management of High Value Timber Species of the Meliaceae, 255, 324-327.

Petit, B., \& Montagnini, F. (2006). Growth in Pure and Mixed Plantation of Trees Species Used in Reforestating Rural Areas of the Humid Region of Costa Rica, Central America. Forest Ecology and Management, Special Issue: Improving Productivity in Mixed-Species Plantations, 233, 195-204.

Poorter, L., Bongers, F., Kouamé, F. Y. N., \& Hawthorne, W. D. (2004). Biodiversity of West African Forests: An Ecological Atlas of Woody Plant Species. Oxon: CAB International. http://dx.doi.org/10.1079/9780851997346.0000 
Seymour, R. S., \& Hunter, M. L. (1999). Principles of Ecological Forestry. In M. L. Hunter (Ed.), Maintaining Biodiversity in Forest Ecosystems (pp. 22-62). Cambridge: Cambridge University Press.

http://dx.doi.org/10.1017/CBO9780511613029.004

Swaine, M. D. (1996). Rainfall and Soil Fertility as Factors Limiting Forest Species Distributions in Ghana. Journal of Ecology, 84, 419-428. http://dx.doi.org/10.2307/2261203

Watt, A. D. (1992). Insect Pest Population Dynamics: Effect of Tree Species Diversity. In M. G. R. Canell, D. C. Malcom, \& P. A. Robertson (Eds.), The Ecology of Mixed-Species Stands of Trees (pp. 267-275). Oxford: Blackwell Scientific Publications.

Watt, A. D. (1994). The Relevance of the Stress Hypothesis to Insects Feeding on Tree Foliage. In S. R. Leather, A. D. Watt, N. J. Mills, \& K. F. A. Walters (Eds.), Individuals, Population and Patterns in Ecology (pp. 73-85). Andover: Intercept. 
Scientific Research Publishing (SCIRP) is one of the largest Open Access journal publishers. It is currently publishing more than 200 open access, online, peer-reviewed journals covering a wide range of academic disciplines. SCIRP serves the worldwide academic communities and contributes to the progress and application of science with its publication.

Other selected journals from SCIRP are listed as below. Submit your manuscript to us via either submit@scirp.org or Online Submission Portal.
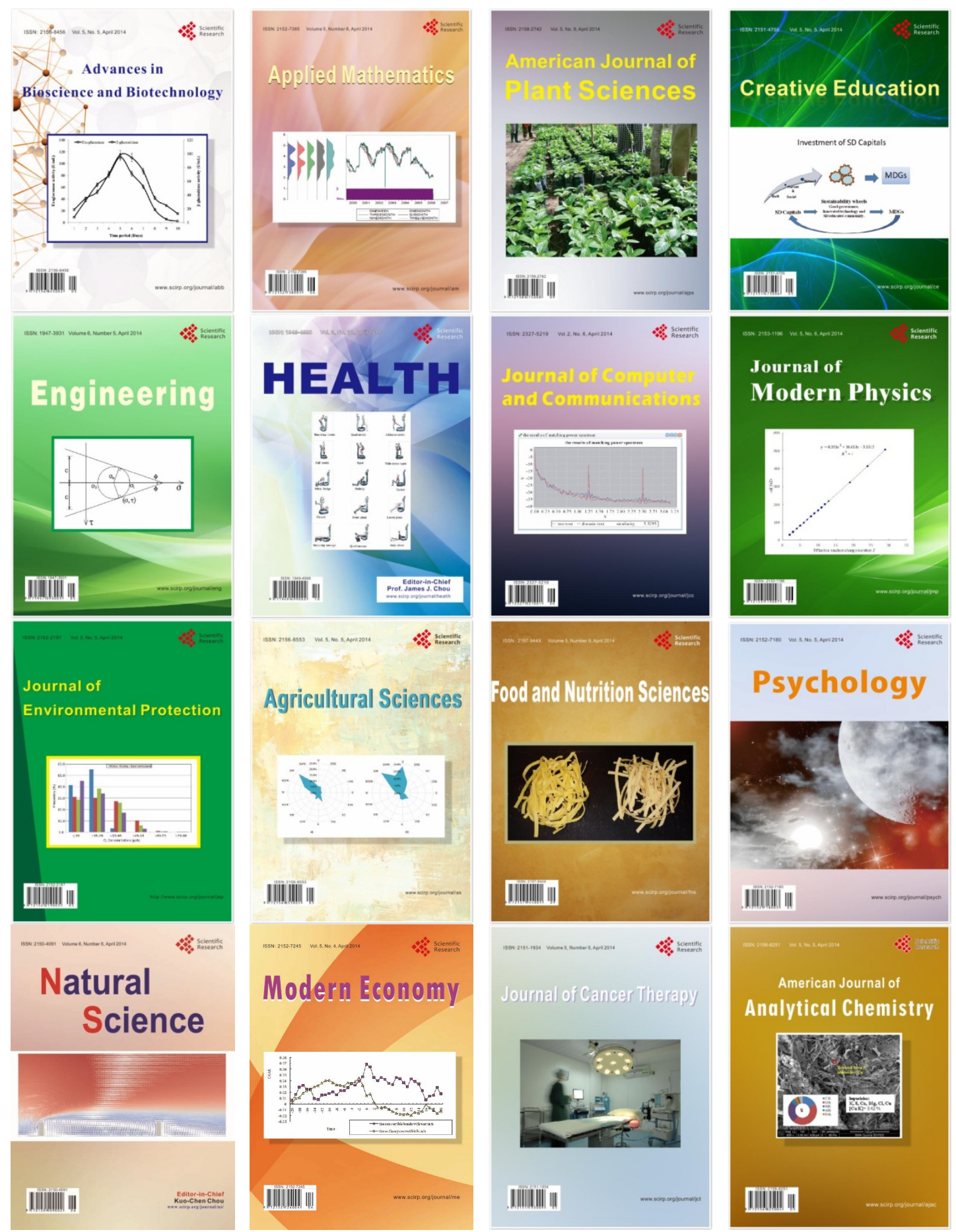